\title{
Theodosian Empresses
}


KENNETH G. HOLUM

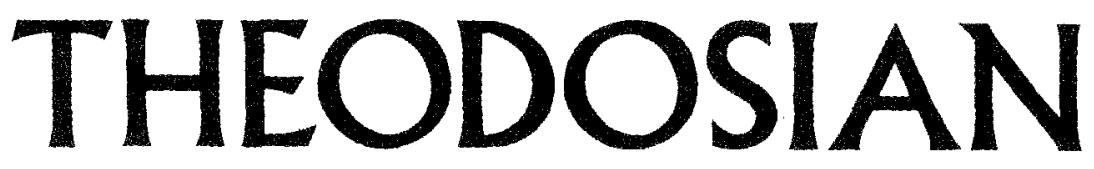

Women and Imperial 


\section{EMPRESSES}

Dominion in

Late Antiquity

UNIVERSITY OF CALIFORNIA PRESS

Berkeley

Los Angeles

London 
University of California Press Berkeley and Los Angeles, California

University of California Press, Ltd. London, England

(c) 1982 by

The Regents of the University of California

Printed in the United States of America

$$
\begin{array}{lllllllll}
1 & 2 & 3 & 4 & 5 & 6 & 7 & 8 & 9
\end{array}
$$

First Paperback Printing 1989

Library of Congress Cataloging in Publication Data

Holum, Kenneth $G$.

Theodosian empresses.

Originally presented as the author's thesis (Ph.D.)-University of Chicago.

Bibliography: $p$.

Includes index.

1. Roman empresses-Biography. 2. Rome-Nobility

-Biography. 3. Rome-History-Theodosians, 379-455.

I. Title. DG322.H64 $1982 \quad 937^{\prime} .02 \quad 81-43690$

ISBN 0-520-06801-7

AACR2 
For Ann,

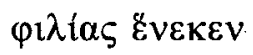


This page intentionally left blank 